University of Nebraska - Lincoln

DigitalCommons@University of Nebraska - Lincoln

\title{
The Historical, Jurisprudential, and Empirical Wisdom of Parental Responsibility Laws
}

\author{
Eve M. Brank \\ University of Nebraska-Lincoln, ebrank2@unl.edu \\ Leroy Scott \\ University of Nebraska-Lincoln
}

Follow this and additional works at: https://digitalcommons.unl.edu/psychfacpub

Part of the Family Law Commons, Juvenile Law Commons, Law and Psychology Commons, and the Psychology Commons

Brank, Eve M. and Scott, Leroy, "The Historical, Jurisprudential, and Empirical Wisdom of Parental Responsibility Laws" (2012). Faculty Publications, Department of Psychology. 975.

https://digitalcommons.unl.edu/psychfacpub/975

This Article is brought to you for free and open access by the Psychology, Department of at DigitalCommons@University of Nebraska - Lincoln. It has been accepted for inclusion in Faculty Publications, Department of Psychology by an authorized administrator of DigitalCommons@University of Nebraska - Lincoln. 

.01034.x by permission.

Published online March 5, 2012.

\title{
The Historical, Jurisprudential, and Empirical Wisdom of Parental Responsibility Laws
}

\author{
Eve M. Brank and Leroy Scott \\ University of Nebraska-Lincoln \\ Corresponding author - Eve Brank, Department of Psychology, University of Nebraska-Lincoln, PO Box 880308, \\ Lincoln, NE 68588-0308, telephone 402-472-3328, email ebrank2@unl.edu
}

\begin{abstract}
The parent-child relationship is woven deep within historical and contemporary culture, but strong retributive ideals have led to blaming parents because of their presumed vicarious role in juvenile crime. The current article will discuss the history, forms, legal challenges, and empirical research related to parental involvement laws in the United States. The parent-child relationship provides the historical framework behind the separate juvenile justice parens patriae system; however, with the juvenile justice system not as successful as originally imagined, blame has shifted to the parents. We examine the potential constitutional implications of enacting and enforcing parental involvement statutes and ordinances and also the potential efficacy of parental involvement laws in reducing juvenile delinquency. In addition, we propose empirical research to test the underlying assumptions about blame made by parental involvement laws.

The great Greek poet, Homer, is credited as saying, "It behooves a father to be blameless if he expects his child to be" (Toliver, 2004). This connection between the wrongs of the father and the wrongs of the son, or to be more contemporary, between a parent and child, is one that has permeated cultures for thousands of years. Across cultures and continents, the parent-child relationship is a staple woven deep within our philosophical and scientific thought, and the U.S. juvenile justice system has capitalized on this cultural emphasis. Specifically, when a minor child is adjudicated delinquent within the juvenile justice system, most states permit recourses against the parents.
\end{abstract}


Consider a recent family in Iowa-mother, Anne, and three children, Holly, Nicholas, and Peter (Hensler v. City of Davenport, 2010). Anne was divorced and raised the children on her own since they were all less than 5 years old. The children were generally wellbehaved and good students until Nicholas experienced some bullying and responded by socially withdrawing from school and sports. At 6'2" tall and 200 pounds, Nicholas was more powerful physically than his mother when the police first cited him for a city curfew violation and possession of marijuana. In addition to Nicholas's school suspension and referral to juvenile court, the city issued Anne a Parental Responsibility Ordinance Warning Letter pursuant to the Davenport Parental Responsibility municipal ordinance (Parental Responsibility, 2006). Despite various attempts by Anne to control Nicholas, he continued to break the laws and Anne received a second citation that resulted in her taking a parenting class and paying for Nicholas's drug rehabilitation program.

Thelma Ephraim, a mother in Ohio, found herself in a similar situation when the prosecutor in Maple City, Ohio, charged her with violating the city's parental responsibility ordinance when her 17-year-old son was arrested and charged with illegal possession of a firearm and resisting arrest. In considering the city's appeal against a municipal court's judgment that the ordinance was unconstitutionally vague and broad, the Court of Appeals of Ohio noted that, "The data permit no firm conclusions as to whether parental responsibility laws are efficacious" (Maple Heights v. Ephraim, 2008, p. 30). In the absence of data, the Ohio court went on to reason that the city ordinance in question was a valid exercise of the city's police power because the city claimed the law reduced juvenile crime. Although the Ohio Court of Appeals ultimately ruled the municipal ordinance invalid because the ordinance imposed vicarious criminal liability contrary to an Ohio state statute that only permitted vicarious criminal liability against organizations, part of the court's opinion suggests both that: (1) empirical evidence concerning effectiveness of the law may have been dispositive, and (2) absent empirical evidence the court is forced to rely on conjecture.

This article explores the legal blameworthiness of parents like those described in the two cases earlier and the dearth of empirical basis for this consanguineous legal obligation. This article is organized around the examination of the types, purpose, appropriateness, and effectiveness of parental involvement laws. As such, in our first section, we examine the history of the laws. Next, we detail the current types and their purposes as developed through legal evolution and social science research. Because of the potential penalties for parents, the laws may be viewed as intrusions into parents' constitutionally protected rights (Tomaszewski, 2005); therefore, our fourth section will address the appropriateness of this method of curbing juvenile crime both through the lens of court attention to the laws and the blame empirical research. In our fifth section, we will expand the appropriateness question by addressing how and why researchers and policy makers should be considering these laws. Despite the ubiquity of these laws, there has been no systematic empirical examination of their effectiveness, and therefore we propose using vicarious blame as the underlying model from which to test how well the laws work at reducing juvenile crime. We briefly outline future research that is desperately needed to answer pressing questions faced by legislators and judges who interact daily with parents and juveniles. 


\section{Historical Background for Parental Responsibility Laws}

Responsibility of parents to care for their children can be thought of as a historical framework for the parens patriae notions behind a separate juvenile justice system. By definition, parens patriae means that the state acts in a capacity similar to that of a parent of a child who needs guardianship; the state is a "superparent" (Singer, 1998) and, like a parent, it can forcibly confer benefits upon people under its control. The state has the right (even duty) to take over where parents fail to ensure the child has a chance at growing up to be a law-abiding citizen (In re Vera Brown, 1904). In the early part of the 1900s, the time corresponding to the first juvenile court, the United States was focusing on the family as a cause and possible solution to delinquent behaviors by juveniles. The country was continuing to learn the value of the assembly line and the integral parts of machines. Life away from the factories was also structured and well-disciplined (West, 1996). It appears as though families too were viewed as automatons; children were the cogs in the machine and the parents were to keep them well-oiled and maintained. If the parents did not fulfill this obligation, evidenced by a child who was delinquent, then the maintenance was to be directed at the parents. This modernist way of thinking brought about the beginning of parental involvement laws as we know them today in the United States. But, the connection between parents' actions and their children's behavior was not a new, industrialized phenomenon.

A relatively cursory search of social, philosophical, and legal thought occurring through history reveals a foreshadowing of parental involvement laws. Clearly, historical documents suggest that parents and children have always had a certain unique relationship, at least to some extent. In what is referred to as the longest and best organized of the Mesopotamian laws, the Code of Hammurabi, provides for us what this king of Babylon set down as the law in 1750 B.C. (Roth, 1997). In this code, it is clear that the act of having children altered the way the law viewed marital obligations. For instance, the Code says that if a man divorces his wife who "bore him children" she is to get back her dowry and one half of her husband's property (p. 107); however, if there were no children then the husband must only restore her bride wealth and dowry. Further, the Code, which is known for its harsh penalties and swift judgment, demonstrates a unique relationship between a father and son. In the topic of disinheriting a son, the Code says that:

If a man should decide to disinherit his son and declares to the judges, "I will disinherit my son," the judges shall investigate the case and if the son is not guilty of a grave offense deserving the penalty of disinheritance, the father may not disinherit his son. If he should be guilty of a grave offense deserving the penalty of disinheritance by his father, they shall pardon him for his first one; if he should commit a grave offense a second time, the father may disinherit his son (p. 113).

This notion of forgiveness and second chances toward the son for his first offense is in stark contrast to the punishments prescribed by the Code for other offenses such as casting 
a wife into the water if she disparages her husband or the same penalty for a woman innkeeper who reduces the value of beer in relation to the value of grain (Roth, 1997).

The Code of Hammurabi provides a 4,000-year-old example of the unique relationship between parents and their children. Similar examples abound throughout history. During its Golden Age, Egypt reflected a culture that glorified the relationship between children and their parents (Chambliss, 1954). The writings of the Egyptian sage, Ptahhotep, demonstrate this with his statement, "People behave as they are taught; therefore, let a father converse with his children so that they in turn will converse with their own children, and thus will wisdom pass down from generation to generation" (Breasted, 2001). Similarly, a Biblical Proverb demonstrates this responsibility of the parents: "Train up a child in the way he should go and when he is old he will not depart from it" (Proverbs 22:6, English Standard Version). Much later, Augustine endorsed the same Biblical notion encouraging parents to be mindful in the raising of their children (Schaff, 1890). Thomas Aquinas, another early Catholic Church leader, fostered parental responsibility for the upbringing of children by encouraging parents to set a good example for their children combined with correction and punishment if necessary (Ostheimer, 1939).

The Renaissance and Reformation, which brought vast cultural shifts elsewhere in daily life, did not bring a complete change to parent-child relationship as children continued to receive their primary instruction from home (Chambliss, 1954). In fact, the antiquated social thought on the family found its way into some more modern systems of law. The Elizabethan Poor Laws provide one of the best and earliest examples of a modern society attempting to legislate this unique parent-child relationship. These laws made poor parents and children responsible for each other. Likewise, the great thinkers of the time continued to uphold the importance of parents. John Locke, sometimes referred to as the Dr. Spock of the 1600s (Borstelmann, 1974), asserted the importance of a good parental example and admonished parents not to do anything that they would not have their children mimic (Yolton \& Yolton, 2003). Several centuries later, the actual Dr. Spock, American pediatrician and popular author in the 1940s and 1950s, was clear that parents were to make their children behave, and children really would not be happy unless their parents did this task effectively (Spock, 1957). Judge Paul W. Alexander has frequently been cited as noting in the late 1940s that people were beginning to discover that delinquent juveniles were traceable to delinquent parents and there was a desire to "curb the former by punishing the latter" (Alexander, 1948).

We know that the concept of childhood has drastically changed over the years (Elrod \& Ryder, 2005); however, the concept of the parent-child relationship has remained fairly static. Even with the cursory breeze through 4,000 years of civilization, the relationship between parents and their children appears to have been a persistent facet of culture present in the earliest of written laws. The Greek philosopher Plato provides the best example of a systematic rejection of the notions of family as we know it. For Plato, the responsibility of being in the Guardian class would be hindered by raising children; however, he still believed procreation was important for the purpose of continuing the best and brightest genetic lines. Therefore, Plato proposed that the wives and children of the Guardians were to be common; that no parent was to know his own child or any child his parent (Reeve, 2004). Albeit no respected society has ever taken Plato's eugenics proposal seriously, 
imagine how different our juvenile justice system would be had Plato's Republic been the historical backdrop when the United States established its juvenile system. Because that is not the historical background, we have a system that was based on the notions of parents caring for their children, but when there is a failure or inability, the state steps in as a substitute parent to care for and control the child's upbringing.

With this parental substitution notion as its heritage, the United States created a separate juvenile court system. Until that time, parents in the United States were given relatively unbridled discretion under the law in how to raise their children (Gardner \& Dupre, 2006). In contrast, with the imposition of the separate juvenile system, the state is now quite involved in regulating how a child is brought into adulthood; when the parents fail in their duty, the state can intervene.

The social experiment of the juvenile court brought with it a flood of hopeful reformers for a new juvenile system and just as many critics. The separate juvenile justice system, which was intended to be a parens patriae alternative to the adult system, began in Illinois in 1899 and quickly spread to every other state (Gardner, 2009). Adolescents were taken away from their parents when they were delinquent and their parents were "unequal to the task of responsibility of controlling and correcting" them so that the child would not continue to be delinquent (People v. Piccolo, 1916).

The juvenile justice system by the 1950s was, ironically, in its adolescence: not in its infancy, but certainly not fully developed. Much like the experience of parents and children during the adolescent years, the system was going through a period of great change and some turmoil. All of the states had some form of juvenile court, but the Supreme Court had not provided much, if any oversight on the decisions that were being issued in those courts (Gardner, 2009). The second half of the 1900s, starting with the Supreme Court's decision in Kent v. United States (1966), was in stark contrast with the earlier laissez faire attitude toward the juvenile system. The new judicial oversight provided juveniles who were being adjudicated delinquent with a number of procedural protections that resulted in their adjudications closely resembling an adult criminal case. The juvenile system prior to this point blended together all juveniles who were in need of some court supervision. The courts made little to no distinction between the dispositions for those who had committed criminal acts and those who had been abused, neglected, or abandoned by their parents. By the 1970s, the differentiation was delineated. Children in need of services and status offenders were treated very differently by the juvenile system from those who had committed delinquent acts (Juvenile Justice and Delinquency Prevention Act, 1972). Personal accountability was placed on juveniles who were adjudicated delinquent and notions of punishment and paying their debts to society become common themes in their dispositions. In contrast, juvenile court efforts to ameliorate the situational effects such as family violence were directed more toward status offenders and especially children in need of services (Gardner, 2009).

In a little over 100 years, the U.S. juvenile court system has become an established segment of American jurisprudence. The state acting as the parent when the parent fails in those duties is the foundation of this system, but what should happen if the state fails as the superparent? This is not just a moot question; by many accounts the juvenile justice system has been largely unsuccessful (Feld, 2007). At approximately the same time, the 
juvenile justice system was going through its first set of major jurisprudential growing pains with Kent v. United States (1966) and its progeny (e.g., Breed v. Jones, 1975; In re Gault, 1967; In re Winship, 1970), state legislators were focusing their attention on blaming and placing responsibility on the custodial or biological parents as a possible answer to the juvenile justice system's problems. In the next section, we will describe the different forms of that legislative response.

\section{Current Types of Parental Responsibility Laws}

The idea that parents should be legally blameworthy for the actions of their children is certainly not new. Under common law negligent tort principles, parents could be required to pay for the damages resulting from the harmful behaviors of their children, but only if the parents' own negligence led to the children's behaviors. Negligent tort cases brought against parents for the actions of their children were difficult to prove because the plaintiffs were required to establish the parents' requisite "duty, breach, causation, and damages" (Ihrie, 1996). Duty is the parent's obligation to exercise care to avoid causing the sort of damage suffered by the plaintiff, and breach is parent's the failure to do so (Goldberg \& Zipursky, 2001). Damages are the harmful consequences of the parent's actions, such as injury or property damage. Causation is the tricky element because the plaintiff must prove not that the child's action brought about the damages, but that there was a causal connection between the parent's behaviors and the harm suffered. The mere parent-child relationship does not satisfy the causal connection, but rather there must be some clear connection between the parent's action (or inaction) and the child's resulting harmful act (Tomaszewski, 2005).

As an alternative to the common law negligence suit against a parent, the juvenile justice system has legislatively created three vehicles for such blame with parental responsibility statutes and ordinances (see Figure 1). Each form serves to formally include the parents when their children are adjudicated delinquent or are status offenders (Brank, Kucera, \& Hays, 2005). The three main forms are: civil liability, contributing to the delinquency of a minor, and parental involvement (Brank et al., 2005). Civil liability statutes, which allow a victim of juvenile crime to bring a civil suit against the parents of the juvenile, are basically strict liability, but have relatively low recovery limits - they range from a few hundred to about two thousand dollars (Brank et al., 2005). Because strict liability claims require no proof of any particular state of mind, it does not matter whether parents were careful. Civil liability is clearly an attempt to right the victim financially and parents are generally in a better place to do that than the juveniles. 


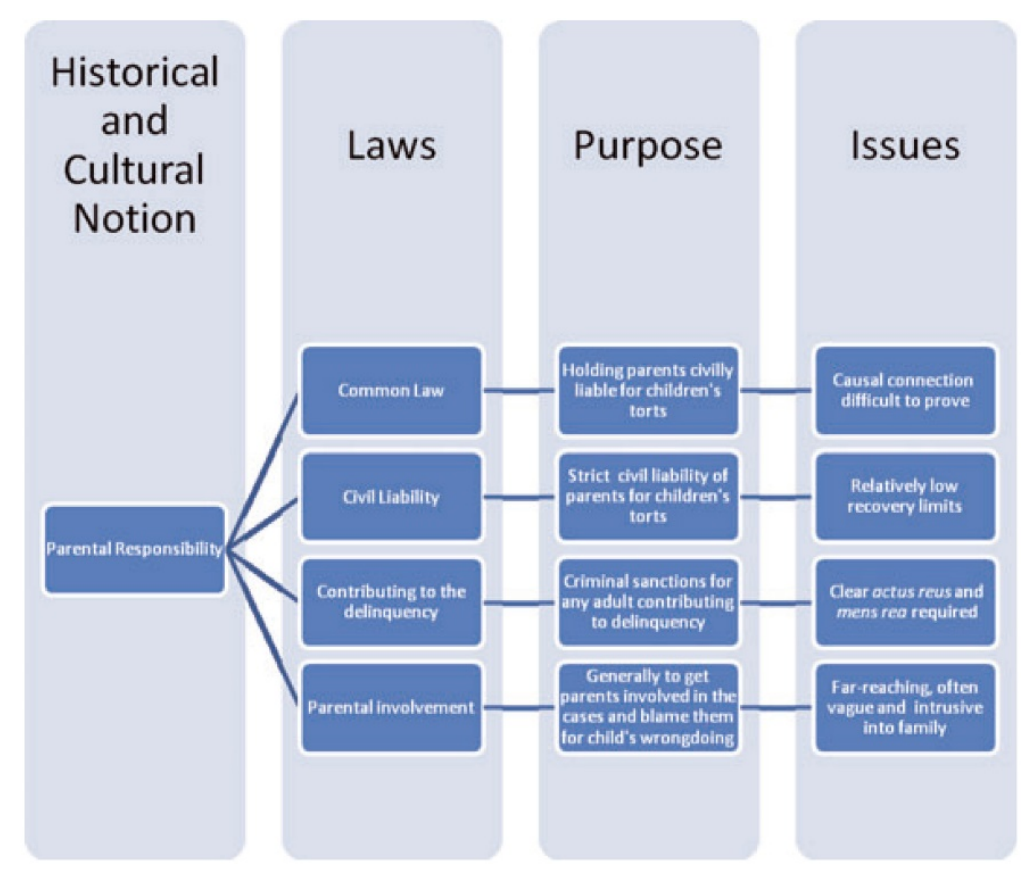

Figure 1. Parental responsibility laws

Contributing to the delinquency of a minor statutes allow for criminal charges to be brought against parents, or any adult, who encourages or aids in a juvenile's delinquent behavior. Such criminal liability requires the actus reus (guilty act) and mens rea (guilty mind) that are generally found in criminal statutes (Scarola, 1997). That is, these laws can sanction parents and other adults when they commit intentional acts or omissions that advance juvenile crime. Such sanctions include fines, jail time, probation, and other options (Brank et al., 2005).

The last form, parental involvement statutes, is much more nebulous and can prove intrusive into the family. Parental involvement laws often require parents to pay for the cost of care or encourage the parents to participate in court hearings when their children commit delinquent acts (Brank et al., 2005). Parents may also need to enroll in parenting classes, pay fines, or do community service. In fact, the options available under these statutes and ordinances appear endless (see Brank et al., 2005). The options expand even more because the laws often also include a "contempt of court" provision that can lead to much harsher penalties if the parents do not fulfill the original sanctions. Parents who want to defend themselves are generally without recourse insomuch as these laws impose a strict liability - a parent is guilty by virtue of being a parent. Notwithstanding the breadth of these laws, enforcement of them in the United States is inconsistent at best (Harris, 2006).

The United States has international company on the issue of parental involvement laws. For instance, the Anti-Social Behaviour Act of 2003 in the United Kingdom purports to address juvenile crime by penalizing parents of chronic juvenile offenders (Arthur, 2005). The act increased the number of situations that could result in parents being ordered to attend parenting classes/counseling and potentially pay fines. Indeed, the United King- 
dom also has a long history of placing legal responsibility on the parents for the actions of their children. As early as 1884 when the Reformatory School Act was enacted, parents could be ordered to pay for the child's cost of care in a reformatory (Arthur, 2005). Similar to the United States, Australian states and territories have legislated that parents are to attend court proceedings, pay for the cost of detaining their child, and participate in other similar activities (White, 2005).

Because each of the parental responsibility law types achieves different goals and requires proofs of different elements, the justifiability and appropriateness of each are different. In particular, because civil liability statutes do not impose punishment, and because contributing to the delinquency of a minor statutes require specific blameworthy conduct by the parents, these two types are more jurisprudentially surefooted than are the parental involvement statutes and ordinances, which can impose criminal sanctions without proof of fault. Notwithstanding that all three types raise similar concerns regarding their social appropriateness; our main emphasis is on the third form - parental involvement laws. The next section will explore the stated and unstated purpose of parental involvement laws.

\section{Purposes of Parental Involvement Laws}

\section{Legal Purposes}

All laws serve a purpose, and parental responsibility laws are no exception. Civil laws provide private parties a way to settle their disputes and be compensated for damages sustained as a result of the intentional or negligent acts of others. Criminal laws allow the government to punish individuals who behave reprehensibly in inflicting harm upon society. Basic criminology teaches us that the six main purposes of punishment generally fall into one of two categories: utilitarian and retributive. Deterrence (general and specific), incapacitation, rehabilitation, and restitution are all utilitarian purposes because they fulfill goals that are forward-looking and desire greater societal benefits. Moral outrage and retribution are retributive because they serve a backward-looking purpose of punishing because the offender deserves the punishment.

When Georgia legislators enacted their parental involvement statute that requires a parent to appear with their child during court proceedings and bring their child before the court when ordered to do so (Procedure on Taking Child into Custody, 2000) they were concerned with sending a message of responsibility to parents. The Georgia General Assembly declared that the parents have a duty and responsibility to instill in their children a respect for the law and the consequences of failing to comply with the law (House Bill 1299, 1996). For the Georgia General Assembly, requiring parents to appear with their children at juvenile proceedings was consistent with such parental responsibility (House Bill 1299,1996 ) and served what they seemed to believe was a utilitarian purpose.

In Nevada, judges have the authority to order juveniles' parents to pay restitution to a victim of the juvenile's crime (Duty of juvenile court to order restitution for certain unlawful acts; responsibilities of parent or guardian of child; community service in lieu of restitution, 2011). The judge may order the parent to perform community service in place of the restitution if the parents' finances are inadequate for the restitution. When the Nevada legislature enacted this statute in 1997, some legislators discussed the importance of send- 
ing a message to parents that they are to be a part of the lives of their children (Nevada Assembly Bill 39, 1997). The legislators noted that the law was intended to not only handle the "offending youth, but the dysfunctional family as well" (Senate Committee on Judiciary, 1997, p.4). One mother testified at the public hearings concerning the bill that she had spoken with a number of parents and children who were all supportive of imposing restitution or community service on the parents (Testimony of Valerie Brown, 1997).

Despite the stated legislated purposes of Georgia, Nevada, and other states, legal scholars have argued that parental involvement laws are unfair because they do not adequately fit within either a utilitarian or retributive purpose (Scarola, 1997). Specifically, it is unknown whether these laws serve the utilitarian purpose of benefiting society -if their benefits outweigh their costs (Scarola, 1997). Additionally, Scarola (1997) argues that the laws do not serve a retributive purpose because most do not require parental culpability.

If parental involvement laws arguably do not serve a utilitarian or retributive purpose, why are these laws so popular? The answer seems to be a combination of the historical undertones described earlier and a legislative reliance on the preponderant and widely known, albeit tangential, scientific knowledge of the time. Not only did the 20th century bring the juvenile court, but it also brought us the boom of social science and empirically based investigations and theories concerning the parent-child relationship.We will review briefly some of the more popular findings because they seem to bolster and espouse the rationalizations for legally imposed parental blame, even though we may question the wisdom of their application.

\section{Popular Social Science Purposes}

The early years of the social science movement, mainly involving Freud's psychoanalytical perspective and Erikson's lifelong stage theory of development, focused on the enduring effects of childhood memories, experiences, and fantasies (Erikson, 1968; Freud \& Strachey, 1962). In fact, according to Freud, all other relationships would emulate the infant and mother relationship. For Erikson, the early years of a child's life and the relationship that child has with her caregivers (generally the parents) form a foundation for later relationships and further development (Erikson, 1950). Other psychologists were also instrumental in advancing theories implicating parents in childhood development. G. Stanley Hall (1904), arguably the founder of the American psychological movement, summarized the teenage years as a time of "storm and stress" caused by physiological changes. He believed that parents held the responsibility to direct children's potentially detrimental behaviors into positive and socially acceptable conduct.

Bronfenbrenner (1986) described the environmental systems that influence children's development and concluded that the family is the primary setting in which children's development occurs, and experiences of the parents, including their income and education, affect children's development. Indeed, Baumrind (1972) distinguished between four different parental discipline styles and posited that the authoritative style, which is marked by parents directing their child's behaviors in a rational manner without being too permissive or too authoritarian, was the best at developing social competence in children. Albert Bandura's influential work on social learning theory and modeling also emphasized the 
role of parents in a child's early development (1977). Bandura (1977) posited that young children will model their parents' behaviors whether those behaviors are good or bad.

In criminology, Social Learning theorists took the position that law-abiding or lawbreaking behaviors are learned from a person's social groups, which include a person's parents (Akers, 1973). Self-control theorists assume that deviant behavior is the result of a breakdown in conventional bonds so that parents fail in providing adolescents with the main attachment to law-abiding behavior (Hirschi, 1969). In Gottfredson and Hirschi's (1990) General Theory of Crime, they posited that parents who have control over their children will have children who grow up to have self-control and that self-control will allow the children to avoid the easy gratification of deviant behaviors. Finally, General Strain theory holds that certain strains or stresses increase criminal activity, with one such strain being parental rejection (Agnew, 2001).

Beyond these general theories, more specific empirical work likely also influenced lawmakers' decisions throughout the past century as they enacted and expanded parental responsibility laws. For instance, research linked parental monitoring and open communication with better grades in school (Crouter,MacDermid, McHale, \& Perry-Jenkins, 1990) and less childhood delinquency (Caprara et al., 1998; Clark \& Shields, 1997). In contrast, children who grow up in hostile homes are more likely to be involved in delinquent behaviors (Smith \& Thornberry, 1995; Widom, 1989; Zingraff, Leiter, Myers, \& Johnson, 1993). In their meta-analysis, Loeber and Schmaling (1985) found several parent factors that predicted later delinquent involvement. The strongest of these predictors were parental rejection, lack of parental involvement, and lack of parental supervision.

Given the popularity of historical, theoretical, and empirical arguments in support of the notion that the wrongdoings of juveniles are the result of faulty or inadequate parenting, it is not surprising that lawmakers looked to blaming parents as a viable strategy for curbing juvenile crime and delinquency. However, it seems that determining the effectiveness of punishing and blaming parents for the behaviors of their children escaped scientific inquiry. A clear relationship between parents and children does not afford justification for blaming or punishing parents. To explain, research has demonstrated a connection between parents' behaviors and children's behaviors, but that connection is tenuous, at best. Not only are the predictive models not perfect, but any number of intervening factors, such as the child's own temperament and personality, can influence outcomes. Further, even if there was a perfect predictive model, we do not know if punishing and blaming the parents will result in specific or general deterrence for either the juveniles or parents. To take this out of the parent-child setting, imagine a university policy that deducts from professors' pay when students fail their classes. Even though educational research has clearly demonstrated that there is a correlation between teaching and student learning, it seems syllogistically irrational to punish faculty in this situation. Similarly, imposing punishments on parents violates legal and social principles, including culpability determinations and appropriate attributions of blame. 


\section{Legal and Social Appropriateness of Parental Involvement Laws}

\section{Legal Scholars and Court Attention Related to Legal Appropriateness}

Legal scholars have addressed one form or another of parental responsibility laws practically since their inception (Gladstone, 1954-1955) with many arguing that the laws are not legitimate exercises of juvenile court power because the nexus is not strong enough between bad parents and bad children (Tyler\&Segady, 2000). Some scholars are especially critical and see parental responsibility laws as nothing more than cheap, symbolic politics (Tomaszewski, 2005), whereas others support at least the concept of requiring parental involvement (Davidson, 1996; Zolman, 1998). Others worry these laws will only continue to perpetrate the disadvantage of single and minority mothers (Cahn, 1996; Laskin, 2000).

The U.S. Supreme Court has not specifically addressed the constitutionality of parental involvement laws, but a number of family law cases are relevant to our current examination. Parents are afforded a constitutionally protected interest in raising their children (Meyer v. Nebraska, 1923) and parental authority in child-rearing is a Supreme Courtrecognized American tradition (Wisconsin v. Yoder, 1972). Freedom of personal choice in matters of family life is a recognized fundamental liberty interest protected by the 14th Amendment (Santosky v. Kramer, 1982). Although the Court has also noted that parents should have the right to raise their children without undue government interference (Ginsberg v. New York, 1968), there is a limit to this right. The family is not beyond regulation in the public interest (Prince v. Massachusetts, 1944). The metaphorical door to the family home is not completely closed but remains partially open depending on the circumstances of the family. Certainly, child maltreatment is one such circumstance that throws wide open the door. Juvenile delinquency, by way of parental involvement laws, may be another time in which the door is opened and the family subjected to more than minor regulations.

Parents sanctioned under all three types of parental responsibility laws have been levying challenges against these laws for several decades (Kelly v.Williams, 1961). Most of the court attention has revolved around the parental civil liability statutes, and most often the courts have held those statutes constitutional (e.g., Bryan v. Kitamura, 1982) because the laws represent the valid state interest of compensating innocent victims (Distinctive Printing and Packaging Co. v. Cox, 1989) and such compensation, arguably, may be unlimited (Caffiero v. Piscataway Township Bd. of Ed., 1981; but see Owens v. Ivey, 1988).

Because the parental involvement type laws are newer and, we believe, on shakier legal ground, we will focus our attention on some cases that have addressed laws that essentially criminalize being a "bad parent" by mandating, for example, that a "parent of a minor shall not fail to exercise reasonable control over said minor" (Davenport Mun. Code $\S 9.56 .010,2006)$.

In an early case, Doe v. City of Trenton (1976), the court addressed a Trenton, New Jersey, ordinance that stated if a minor was charged and adjudicated delinquent for violating public peace twice in a year, "it shall be presumed, subject to rebuttal ... that the parents ... allowed, permitted or suffered [the] minor to commit a violation of the public peace." Although the ordinance technically required parental fault, it allowed such fault to be presumed from the existence of prior delinquencies of a minor. Legal presumptions are unconstitutional if they are "irrational" or "arbitrary," and therefore, for a presumption to be 
constitutional, a proven fact must give the "substantial assurance" that the presumed fact more likely than not flowed from the proven fact (Leary v. United States, 1969). In finding the ordinance unconstitutional, the New Jersey court reasoned that the causes of juvenile misconduct are "complex and imperfectly understood" (Leary v. United States, 1969, p. 132), and because the city provided no evidence that parental influence is an overriding cause of juvenile misconduct, it cannot be said that the "presumed fact in the Trenton ordinance (parental responsibility for delinquent acts of the child) [flowed] naturally from the proved fact (a second adjudication within one year)" (Doe v. City of Trenton, 1976, p. 133).

More recently, the courts have been similarly unsupportive of parental involvement laws but not for constitutional reasons. Two cases in Ohio demonstrate this well. First, in Struthers v. Ardale (2000), a father successfully argued that a parental involvement charge brought against him did not inform him of the elements of the crime or the specific nature of his crime. As a result of his son's truancy, the father received a citation that stated, "On 3-22, 1999, at Struthers High School Struthers Ohio you violated parental responsibility Ord. \#97-9562" (Struthers v. Ardale, 2000, p.1). The court ordered the father to pay a $\$ 20$ fine and pay court costs. On appeal, the father successfully argued that the citation he received did not inform him of the nature and cause of the accusation against him. The court avoided the father's other argument that the city's ordinance requiring "No parent or guardian of any minor child under the age of eighteen years shall fail to exercise reasonable control over said minor" (Struthers v. Ardale, 2000, p. 1) should be void for vagueness.

The second Ohio case similarly circumvented a constitutional argument but still struck down a parental involvement statute for being in conflict with state law (Maple Heights v. Ephraim, 2008). In Maple Heights, a parent commits the "offense of failing to supervise a minor if . . . the child has committed a status offense, unruly act or a delinquent act that would be a misdemeanor or felony of any degree if committed by an adult" (Maple Heights v. Ephraim, 2008, p. 442). The Ohio Court of Appeals held that the Maple Heights' parental involvement ordinance was in conflict with not only the common law disapproval of vicarious criminal responsibility but also with Ohio's statutory prohibition of vicarious criminal liability on individuals.

In Michigan, the state ordered parents to pay over $\$ 700,000$ in restitution (a criminal sanction) after their son vandalized and set several fires in a high school (In re McEvoy, 2005). The parents argued unsuccessfully that permitting an unlimited amount of restitution without showing of parental fault unconstitutionally deprived them of substantive due process. The court reasoned that the statute did include a parental fault consideration because the law is imposed only against those parents who had "supervisory responsibility for the juvenile at the time of the [illegal] acts" (In re McEvoy, 2005, pp. 69-70). The parents also unsuccessfully argued that the parental involvement statute acted as a bill of attainder. A bill of attainder is a law that circumvents the judicial function and simply punishes a specifically designated person or group. Bill of attainders have been described as "trial by legislature," the implication being that the laws so specifically targets a specific person or group that there is nothing left for the courts to do (United States v. Brown, 1965). In this instance, parents' paying restitution was based on their status of being parents. The court rejected this argument by reasoning that the required punishment element was missing. The court reasoned that "the mere fact that harm is inflicted by the government does 
not make it punishment" (In re McEvoy, 2005, p. 73). Moreover, even though restitution is meant to cause "financial pain" it is not automatically punishment (In re McEvoy, 2005, p. 73).

Most recently, the Supreme Court of Iowa held that a parental involvement ordinance was arbitrary and irrational (Hensler v. City of Davenport, 2010). In Davenport, Iowa, a parent fails "to exercise reasonable parental control" over a minor if there is a second "occurrence" or "adjudication" or "entry of informal adjustment" related to any unlawful act by the minor. An "occurrence" means that a law enforcement agency had probable cause that the minor is delinquent and takes the minor into custody. The existence of this presumption clause saved the city the burden of proving that the parent failed to exercise reasonable control and that failure caused the "occurrence." The Supreme Court of Iowa held that such a presumption was irrational and arbitrary because juvenile delinquency can be caused by many different factors, and experts fail to agree on the causes of delinquency (Hensler v. City of Davenport, 2010). The court therefore struck down this provision of the ordinance, but preserved the other provisions of the ordinance that did not offend the due process guarantees of the U.S. Constitution (Hensler v. City of Davenport, 2010). In rejecting the parent's claim that the law unconstitutionally infringed on her parental rights, the court held that "while the ordinance does attempt to inform parents about their child's delinquency, provide skills for combating delinquency, and ultimately imposes sanctions on parents for their child's continued delinquency, we cannot say the city has improperly intervened and substituted its decision making for that of the parent" (Hensler v. City of Davenport, 2010, p. 9) This tautological reasoning, however, seems to reach a conclusion that is inconsistent with the premise upon which it is based. Specifically, if the government is subjecting parents to criminal penalty for failing to properly implement the parenting skills required by the government, then the government is indeed substituting its decision making for that of the parents.

The preceding recent cases demonstrate that courts are more willing to enforce civil liability ordinances than they are to enforce parental involvement ordinances. Courts often attack the constitutional issues head-on in the civil liability cases but more often avoid those difficult constitutional issues for parental involvement laws. The difference in approaches could be the result of a conflict between lay people and legislators' desire to blame parents and the limits imposed by the United States and state Constitutions on punishing people who did not engage in blameworthy conduct. By striking down statutes on grounds unrelated to the Constitution, courts do not have to publicly proclaim that theConstitution prohibits us from compelling good parenting through threat of legal sanction. Analyzing these laws under constitutional doctrines could force the government to prove that these laws work and are narrowly tailored to achieve the state's goal. Based on the current lack of research on the effectiveness of these laws, it is unlikely that the government would be able to prove its case. Our next section attends specifically to the kinds of empirical research that are needed.

\section{Empirical Research Related to Social Appropriateness}

We discussed earlier the historical background of parental involvement laws and the possible theoretical and empirical reasons for targeting parents in the attempt to remedy and discourage juvenile delinquency. As stated earlier, parental responsibility laws can be 
organized into three types: civil liability, contributing to the delinquency of a minor, and parental involvement statutes (see Table 1). Although each of these types serves different purposes, the ultimate effect of the laws is to saddle parents with the burden of rectifying the harms of their children. Perceptions of the social appropriateness of parental responsibility laws generally, and parental involvement laws more specifically, might therefore be based on people's implicit notions of blame.

Table 1. Examples of Parental Responsibility Laws

\begin{tabular}{|c|c|}
\hline Type & Example Law \\
\hline Civil Liability & $\begin{array}{l}\text { Idaho } \S 6-210 \text {, "Any person shall be entitled to recover damages in an } \\
\text { amount not to exceed two thousand five hundred dollars }(\$ 2,500) \text { in a } \\
\text { court of competent jurisdiction from the parents of any minor, under the } \\
\text { age of eighteen (18) years, living with the parents, who shall willfully cause } \\
\text { economic loss to such person..." }\end{array}$ \\
\hline $\begin{array}{l}\text { Criminal Liability/Contributing } \\
\text { to the Delinquency }\end{array}$ & $\begin{array}{l}\text { Mississippi } \S 97-5-39, \text { “. . . any parent . . . who willfully commits any act } \\
\text { or omits the performance of any duty, which act or omission contributes } \\
\text { to or tends to contribute to the neglect or delinquency of any child ... shal } \\
\text { be guilty of a misdemeanor, and upon conviction shall be punished by a } \\
\text { fine not to exceed One Thousand Dollars }(\$ 1,000.00) \text {, or by imprisonment } \\
\text { not to exceed one (1) year in jail, or by both such fine and imprisonment." }\end{array}$ \\
\hline General Involvement & $\begin{array}{l}\text { Nebraska } \S 43-290 \text {, "to promote parental responsibility and to provide for } \\
\text { the most equitable use and availability of public money ... the court may } \\
\text { order and decree that the parent shall pay, in such manner as the court } \\
\text { may direct, a reasonable sum that will cover in whole or part the support, } \\
\text { study, and treatment of the juvenile, which amount ordered paid shall be } \\
\text { the extent of the liability of the parent." }\end{array}$ \\
\hline
\end{tabular}

Assignment of blame to parents is bolstered, although arguably illogically, by psychological theories and empirical findings that parents' actions influence children's behaviors. Therefore blame, in contrast to responsibility and culpability (Shaver \& Drown, 1986), is the logical first step in examining the social appropriateness of parental involvement laws because these laws uniquely use blame. Blame involves evaluating a person negatively; responsibility involves evaluating the relationship between a person and an outcome, and culpability involves evaluating the mental state of a person as she engaged in an action. Therefore if parental involvement laws are manifestations of parental blame, then sanctions are imposed because of parental status and not because of specific behaviors that parents have done. Not requiring proof of specific blameworthy behaviors is in direct contrast to other laws directed at parents. Child neglect and abuse statutes, for example, typically impose liability upon parents only when they, through an act or omission to act, endangered or harmed the child.

Parental involvement laws essentially impose vicarious liability onto parents for the acts of their children. However, unlike other forms of vicarious liability situations where two parties may be linked only by a particular crime (e.g., accomplice or conspiratorial liability) or by a limited, consensual relationship (e.g., liability of employers for torts of employees during the course of employment), parental involvement laws expose parents to potentially endless, unforeseen burdens. Parental involvement laws are predicated on the 
premise that parents are to blame because of the parent-child relationship; no specific definable action or inaction is required of the parents.

Blame is a central feature of religious scriptures, ethics, moral philosophy, criminal law, and civil law (Robinson, 2002). Yet, the majority of empirical and theoretical attention has been devoted to the attribution of other-blame - that is, the ways in which others attribute blame to a wrongdoer. Newer but less frequent foci have been on self-blame and the effects (e.g., emotional or relational) of blame on the blame recipient. These new foci of blame research can prove important in evaluating the social appropriateness of blaming parents for the acts of their children. Each of these areas of blame research will be explored in this section and applied to the particular social appropriateness of parental involvement laws.

\section{Attributions of other-blame}

Read any news report or listen to friends discuss a tragic event and blame will likely be part of the story. Attributions of blame are at the forefront when a negative event occurs (Anderson, 1991; Shaver, 1985). However, despite blame's ubiquity, it is somewhat unclear what blame is and what purpose it serves (Scanlon, 2008). Some theoretical explanations of blame attributions prescribe how an ideal rational actor should make judgments of blame. For example, in Shaver's (1985) classic book, he outlines the five dimensions as: (1) the actor's contribution to the harm (causality); (2) the actor's awareness of the consequences of her action (knowledge); (3) the actor's desire to bring about the consequence (intentionality); (4) the actor's freedom (lack of coercion); and (5) the actor's appreciation of the moral wrongfulness of the action. As each of these dimensions increases, so too should the attribution of blame. More recently, Alicke (2000) advanced a more contemporary and empirically supported culpable control model (Lagnado \& Channon, 2008). In Alicke's (2000) model, the attribution of blame is based on the two main processes: making spontaneous affective evaluations and assessing the actor's personal control over the harmful outcome (blame validation).

Research has demonstrated that a number of factors influence observers' attribution of blame. The observer's own characteristics (Rusinko, Bradley, \& Miller, 2010; Stuewig Tangney, Heigel, Harty, \& McCloskey, 2010), ideologies (Sleath \& Bull, 2010), and emotions (Feigenson \& Park, 2006; Kulik \& Brown, 1979; Meier \& Robinson, 2004;) influence the way people make blame judgments. Likewise, the actors' motivations (Alicke, 2000), mental state (Alicke, Buckingham, Zell, \& Davis, 2008; Mazzocco, Alicke, \& Davis, 2004), social attractiveness (Alicke \& Zell, 2009), and causal control (Alicke, 2000) influence the amount of blame attributed to them. Even characteristics of the situation such as severity of outcomes (Mazzocco et al., 2004), characteristics of victims (Cramer, Chandler, \& Wakeman, 2010), and social pressure on the actor (Tetlock, Self, \& Singh, 2010) can influence the way people make blame attributions. Blame seems to serve the purpose of reassuring people that they live in a "Just World" (Lerner, 1970); that is, people blame victims because of the belief that people get what they deserve (Lerner \& Matthews, 1967). When we blame, we are appealing to some sort of justice-we are focusing on what someone ought to receive (Tilly, 2008). Yet, as Alicke (2008) notes, academics may generally agree with how to appropriate blame, but everyday blamers and our criminal justice system commonly violate the scholarly definitional requirements. Alicke (2000, FN2) also notes that blame for 
parents rests on the presumption that the parents have been ineffective or deleterious in their child-rearing and therefore worthy of blame for their child's actions. Lawmakers have relied on this presumption to justify punishing parents for juvenile delinquency, but such reliance violates the scholarly definitional requirements of attributing blame.

Attributions of self-blame

Although attributions of other-blame is integral to understanding legislative reasoning for parental involvement laws, the laws' appropriateness partially rests on the ways in which the parents self-blame. As the preceding section demonstrates, research and theoretical thought have often focused on attributions of blame that are directed by one person to another person; however, attributions of blame can also be self-directed. Self-blame, according to attribution theory, allows a person to make causal attributions about a negative event, which may elicit a sense of control over that event and future events like it. Research findings are mixed; however, on whether self-blame leads to better adaptation. In certain instances, self-blame seems to lead to better outcomes (e.g., Affleck, Allen, Tennen, McGrade, \& Ratzan, 1985; Bulman \& Wortman, 1977), but in other similar situations selfblame seems to lead to worse outcomes (e.g., Affleck et al., 1985; Branscombe,Wohl, Owen, Allison, \& N'gbala, 2003; Taylor, Lichtman, \& Wood, 1984).

One potential explanation for the different outcomes is the distinction between behavioral versus characterological self-blame that Janoff-Bulman first noted in 1979. As the terms suggest, behavioral self-blame results when the negative events are attributed to one's behaviors - the specific actions or inactions. Inherent in this definition is that behaviors are modifiable and can be avoided in the future. Characterological self-blame results when the negative events are attributed to one's character and are, therefore, essentially immutable. Similar to the way a person blames someone else, a person can blame himself behaviorally (as opposed to characterologically) as a way to control the potential repetition of the negative event. As an example, Tennen, Affleck, and Gershman (1986) asked mothers of infants with severe medical problems about their infants' health difficulties and their own self-blame for those difficulties. Each mother was also asked about her own blame for her infant's recovery and future health issues. Mothers who behaviorally self-blamed displayed better mood-states. Explained through defensive attribution theory, these results indicate that as the severity of the illnessworsens, it becomes even more unpleasant to believe that the mother did not have control and that such misfortune could strike again in the future. Might juvenile delinquency be viewed similarly by parents?

\section{Transferring other-blame to self-blame}

Although considerable research and theoretical explanations exist on the attribution of blame, little to no research has examined whether other-blame can be successfully transferred into self-blame. The research dearth is even greater when the attribution is directed at a person, such as a parent, who may be vicariously responsible. Both foci are important in understanding everyday interactions that involve blame and are especially important in forming a theoretical foundation for empirically testing parental involvement laws. Determining how to shape blame in such a way as to encourage drive and agency without 
undermining motivation is a "pressing question" for social psychology and philosophy (Springer, 2008, p. 413).

Anderson (1991) notes that admissions or apologies, in contrast to excuses and justifications, may serve as behavioral indications of blame-acceptance and imply that the person has moved from being the target of other-blame to self-blame, but this has not yet been empirically tested. Parkinson and Illingworth (2009) examined other-blame and selfblame, but for the purposes of guilt inducement. In a series of three small-sample diary and retrospective recall studies, Parkinson and Illingworth (2009) found guilt can result from other-blame even when self-blame is not present. Although Parkinson and Illingworth (2009) considered other- and self-blame together, their methodology was not intended to examine information about whether and how a person would transform otherblame to self-blame. Additionally, Kassin and Kiechel (1996) in their false confession paradigm showed a majority of participants who were presented with false incriminating evidence accepted responsibility for "their" actions and about one-fourth actually internalized the false evidence.

Targets of blame (from other or self) will most often experience shame, guilt, anger, or indignation with shame and guilt leading to more positive and mutable outcomes (Baumeister, Stillwell, \& Heatherton, 1994; Van Vliet, 2009). Because other-blame inherently relates to a desire to reform the blame recipient (Williams, 2003), other-blame can benefit the recipient (target of blame) by communicating to the person being blamed that she is a legitimate candidate for change (Holroyd, 2007). But people seem to try to avoid blame even when there is no potential for punishment (Anderson, 1991). This may be because blame is inherently commingled with control, which can easily lead to undermining motivation for the person being blamed (Springer, 2008). Because intrinsic motivation depends upon feeling competent and autonomous, evaluative feedback, such as blame, can backfire if it results in the recipient feeling less competent or less autonomous (Deci \& Ryan, 1985). Further, Robinson (2002) posits that if not done correctly, the person being blamed may become angry and indignant.

For the purpose of parental involvement laws, can other blame be transferred into more useful and adaptive self-blame (whether behavioral or characterological)? It is clear that attributions of other-blame are wielded within parental involvement laws, but to what result? In our next section, we address the question of whether parental involvement laws are efficacious.

\section{Effectiveness of Parental Involvement Laws}

Psychology and criminology theorists purport that parents do have an influence in their children's criminal behaviors, but there is also a strong influence of peers and environmental factors (Weijters, Scheepers, \& Gerris, 2009). Moreover, research has focused on models to predict delinquency, not interventions that blame parents. Not only has this type of intervention been empirically neglected, but the courts have noted this neglect (Maple Heights v. Ephraim, 2008). As social scientists we often advocate evidence-based legal decision making (Boruch, 2005), but with parental involvement laws we have very little germane to the questions of their effectiveness. Despite their popularity among lawmakers, 
we know an inappreciable amount about the effects of vicarious blaming; such paucity in the research suggests this area, and the policy implications that follow, is ripe for empirical examination.

Empirical research on the general topic of parental responsibility laws has been limited at best. Much of the work done at this point has focused on the legal analysis of the laws (Brank et al., 2005; DiFonzo, 2001; Thurman, 2003), enforcement frequency (Harris, 2006), or public opinion of the laws. Such public opinion research has demonstrated that the laws are not as widely supported by the general public as the political pundits and policy makers would argue (Brank \& Weisz, 2004; White, Augoustinos, \& Taplin, 2007).

Brank and Weisz (2004) conducted a large-scale nationally representative survey about issues related to parental responsibility laws. The survey results demonstrated that respondents generally place a great deal of responsibility on the juveniles and are not that enthusiastic in their desires to blame or punish parents. Consistent with other global versus specific research, Brank, Hays, and Weisz (2006) found that participants were more reluctant to support the notion of parental responsibility when there are specific juveniles and parents described than when they are asked generally about the topic. In a series of three studies, Brank, Greene, and Hochevar (2011) examined the impact of various situational and dispositional factors on public opinion regarding parental responsibility. Most responsibility was placed on the child, with attributions of responsibility on the parents decreasing as the described juvenile's age increased. Other factors such as the type of crime and the parents' described actions did not consistently influence responsibility attributions (Brank et al., 2011). Adjudicated delinquent juveniles also tend not to support the notions of parental responsibility and blame. Brank and Lane (2008) interviewed adjudicated delinquent youth living in residential facilities and found that a vast majority of the youth said their parents were not responsible for their crimes.

No widespread and empirically sound research has examined the use and effectiveness of parental responsibility laws, but some related research has demonstrated that an intensive probation program focused on improving parent-child relationships did not significantly improve key family relationship measures (Brank, Lane, Turner, Fain, \& Sehgal, 2008). We suggest and describe later in this section that vicarious blame and transferring other-blame into self-blame provides a theoretical framework from which to test their legal viability.

One luxury of parental involvement laws that other forms of correction do not have is that these are not the primary disposition for a juvenile. This makes it relatively easy to randomly assign some parents to sanctions and others not. With judicial willingness and involvement, we could conduct controlled experiments with random assignment that would allow for relatively clear comparisons. For instance, consider a Jacksonville, Florida ordinance (Children's Curfew, 2006) that allows parents to be fined $\$ 100$ when one of their children breaks the city's curfew, but permits the parents to either go to a parenting class or do community service in lieu of the fine. Two of the stated purposes are to: "[P]rotect the children from the dangers of violent crimes which occur on and in the sidewalks, streets, public places and other places accessible to the public during late night hours throughout the city" and "[P]rotect the persons of this City from the dangers of violent crime committed by children on the sidewalks, streets, public places, and other places 
accessible to the public during late night hours." The Jacksonville ordinance only added the parental component to their existing curfew ordinance, which would easily allow for pre- and postimplementation comparisons.

The types of parental sanctions also provide a natural way to manipulate manifestations of blame. Parents could be randomly assigned to receive one of the three sanction options or no sanction at all. The community service and fine sanctions suggest a characterological blame strategy, whereas the parenting class suggests behavioral blame. With city cooperation even more in-depth blame manipulations would be possible such that parents are explicitly blamed in either a characterological or behavioral way. In addition to simple comparisons of rates of delinquent behavior, interviews with parents could be modeled after research that has examined mothers' self-blame for their infants' health (Tennen et al., 1986). Such interviews would allow researchers to probe into the parents' causal attributions and self-blame for their child's delinquency, their judgments of personal control and self-blame over future offenses, and their belief about avoidance of similar delinquency in their other children. This would be especially important and telling if done in conjunction with random assignment to the different parental sanctions.

Additional methodologies, such as propensity score matching (PSM) statistical techniques (Rosenbaum \& Rubin, 1983), could prove useful in communities where controlled experiments are not feasible. PSM would allow researchers to statistically identify similar groups of juveniles and their parents (Hill, Waldfogel, Brooks-Gunn, \& Han, 2005) while decreasing selection bias. Even quasi-experimental designs would prove useful in building the beginnings of a knowledge base about these laws. Methods such as interrupted time series designs (Ferron \& Rendina-Gobioff, 2005) for cities that allowed access to juveniles, but not random assignment; or regression-discontinuity design when juvenile court judges want "specific" parents to get the "treatment" of the parental sanctions (Thistlethwaite \& Campbell, 1960)

We chose to focus our empirical review on the notion of blame, but clearly there are other areas with important implications for developing a comprehensive empirical review of parental involvement laws. For instance, the social psychological principles of reward and punishment (Greitemeyer \& Weiner, 2008) seem particularly relevant, as does the work on extrinsic versus intrinsic motivation (Ginsburg \& Bronstein, 1993). Despite these and other potential areas of inquiry, the theoretical models of other- and self-blame provide an expedient foundation.

\section{Conclusion}

At this point, it is unclear whether parental responsibility laws are an appropriate legal response to juvenile delinquency. The parent-child relationship is deeply rooted in our societal history and the U.S. juvenile system clearly attempted to mirror that relationship in creation of the juvenile court and capitalize on the relationship with the imposition of parental involvement laws. The question remains whether such vicarious blame that accompanies parental involvement laws are an empirically and legally valid response to juvenile delinquency. 
Psychology and criminology research indicates that parents should and do play a role in the upbringing of a socially competent child, but no research has yet confirmed that the policy of imposing postcrime blame for parents' behaviors or character will have any positive influence on juvenile crime. The fictional mother in Peter Shaffer's play Equus provides a poignant conclusion to our inquiry. Her brief monologue exemplifies not only the distraught parental response to a child's crime, but also the way that the parent-child relationship has permeated our laws and our culture. The mother responds to the psychiatrist's inquiries:

And me? What about me? What do you think I am? I'm a parent, of course-so it doesn't count. That's a dirty word in here, isn't it, 'parent.' . . . I've heard it all my life. It's our fault. Whatever happens, we did it ...We're not criminals.We've done nothing wrong.We loved Alan. We gave him the best love we could ... No, doctor. Whatever's happened has happened because of Alan. Alan is himself. Every soul is itself. If you added up everything we ever did to him, from his first day on earth to this, you wouldn't find why he did this terrible thing-because that's him: not just all of our things added up ... (Shaffer, 1974, p. 77).

Our belief is that as a society we will not be able to answer this fictional mother's questions and respond to her statements until we have adequately tested the behavioral assumptions imposed by parental involvement laws.

Acknowledgments - The first author thanks Charles Frazier for his helpful input on this article and in the first author's career and life in general. Portions of this research were supported by a University of Nebraska Research Council Faculty Seed Grant.

\section{References}

Affleck, G., Allen, D. A., Tennen, H., McGrade, B. J., \& Ratzan, S. (1985).Causal and control cognitions in parent coping with chronically ill child. Journal of Social and Clinical Psychology, 3, 369-379. doi:10.1521/jscp.1985.3.3.367

Agnew, R. (2001). Building on the foundation of general strain theory: Specifying the types of strain most likely to lead to crime and delinquency. Journal of Research in Crime and Delinquency, 38, 319361. doi:10.1177/0022427801038004001

Akers, R. L. (1973). Deviant behavior: A social learning approach. Belmont, CA: Wadsworth Publishing Company, Inc.

Alexander, P. W. (1948). What's this about punishing parents? Federal Probation, 12, 23-29.

Alicke, M. D. (2000). Culpable control and the psychology of blame. Psychological Bulletin, 126, 556574. doi:10.1037//0033-2909.126.4.556

Alicke, M. D. (2008). Blaming badly. Journal of Cognition and Culture, 8, 179-186. doi:10.1163/ $156770908 \times 289279$

Alicke, M. D., Buckingham, J., Zell, E., \& Davis, T. (2008). Culpable control and counterfactual reasoning in the psychology of blame. Personality and Social Psychology Bulletin, 34(10), 1371-1381. doi: $10.1177 / 0146167208321594$ 
Alicke, M. D., \& Zell, E. (2009). Social attractiveness and blame. Journal of Applied Social Psychology, 39(9), 2089-2105. doi:10.1111/j.1559-1816.2009.00517.x

Anderson, N. H. (1991). Psychodynamics of everyday life: Blaming and avoiding blame. In N. H. Anderson, Contributions to Information Integration Theory, 2 (pp. 243-275). Hillsdale, NJ: Lawrence Erlbaum Associates.

Arthur, R. (2005). Punishing parents for the crimes of their children. The Howard Journal of Criminal Justice, 44 (3), 233-253. doi:10.1111/j.1468-2311.2005.00370.x

Bandura, A. (1977). Social learning theory. Oxford, UK: Prentice-Hall.

Baumeister, R. F., Stillwell, A. M., \& Heatherton, T. F. (1994). Guilt: An interpersonal approach. Psychological Bulletin, 115, 243-267. doi:10.1037/0033-2909.115.2.243

Baumrind, D. (1972). The development of instrumental competence through socialization. In A. D. Pick (Ed.), Minnesota Symposia on Child Psychology: Oxford, UK: University of Minnesota Press.

Borstelmann, L. J. (1974). Dr. Locke and Dr. Spock: Continuity and change in American conceptions of childrearing. Paper presented at the Southeastern Regional Meeting of the Society for Research in Child Development. Chapel Hill, North Carolina. Retrieved February 9, 2011 from http://www .eric.ed.gov/PDFS/ED099140.pdf.

Boruch, R. (2005). Better evaluation for evidence-based policy: Place randomized trials in education, criminology, welfare, and health. The Annals of the American Academy of Political Social Science, 599, 6-17.

Brank, E. M., Greene, E., \& Hochevar, K. (2011). Holding parents responsible: Is vicarious responsibility the public's answer to juvenile crime? Psychology, Public Policy and the Law, 17(4), 507-529.

Brank, E. M., Hays, S.A., \& Weisz, V. (2006). Global and specific attitudes toward parental responsibility. Journal of Applied Social Psychology, 36, 2670-2684. doi:10.1111/j.0021-9029.2006.00122.x.

Brank, E. M., Kucera, S. C., \& Hays, S. A. (2005). Parental responsibility statutes: An organization and policy implications. Journal of Law and Family Studies, 7, 1-55.

Brank, E. M., \& Lane, J. (2008). Punishing my parents: Juveniles' perspectives on parental responsibility. Criminal Justice Policy Review, 19, 333-348. doi:10.1177/0887403407311956

Brank, E. M., Lane, J., Turner, S., Fain, T., \& Sehgal, A. (2008). An experimental juvenile probation program: Effects on parent and peer relationships. Crime and Delinquency, 54, 193-224.

Brank, E. M., \& Weisz, V. (2004). Paying for the crimes of their youth: Public support of parental responsibility laws. Journal of Criminal Justice, 32, 465-475. doi:10.1016/j.jcrimjus.2004.06.010.

Branscombe, N. R., Wohl, M. J. A., Owen, S., Allison, J. A., \& N'gbala, A. (2003). Counterfactual thinking, blame assignment, and well-being in rape victims. Basic and Applied Social Psychology, 25, 265-273. doi:10.1207/S15324834BASP2504_1

Breasted, J. H. (2001). Ancient records of Egypt, Vol. I: The first through the seventeenth dynasties. Champaign, University of Illinois Press.

Breed v. Jones, 421 U.S. 519 (1975).

Bronfenbrenner, U. (1986). Ecology of the family as a context for human development: Research perspectives. Developmental Psychology, 22(6), 723-742. doi: 10.1037/0012-1649.22.6.723

Bryan v. Kitamura, 529 F.Supp. 394 (1982).

Bulman, R. J., \&Wortman, C. B. (1977). Attributions of blame and coping in the "real world": Severe accident victims react to their lot. Journal of Personality and Social Psychology, 35, 351-363. doi:10.1037// 0022-3514.35.5.351

Caffiero v. Piscataway Township Bd. of Ed., 454 U.S. 1025 (1981). 
Cahn, N. R. (1996). Juvenile justice reform: Pragmatic questions about parental liability statutes. Wisconsin Law Review, 1996, 399-445.

Caprara, G. V., Scabini, E., Barbaranelli, C., Pastorelli, C., Regalia, C., \& Bandura, A. (1998). Impact of adolescents' perceived self-regulatory efficacy on familial communication and antisocial conduct. European Psychologist, 3, 125-132. doi:10.1027//1016-9040.3.2.125

Chambliss, R. (1954). Social thought: From Hammurabi to Comte. New York: The Dryden Press.

Children's Curfew, Jacksonville Ordinance, Chapter 603, from Ordinance 2006-889-E § 2 (2006). Clark, R. D., \& Shields, G. (1997). Family communication and delinquency. Adolescence, 32, 81-89.

Cramer, R., Chandler, J., \& Wakeman, E. (2010). Blame attribution as a moderator of perceptions of sexual orientation-based hate crimes. Journal of Interpersonal Violence, 25(5), 848-862. doi: 10.1177/ 0886260509336962

Crouter, A. C., MacDermid, S. M., McHale, S. M., \& Perry-Jenkins, M. (1990). Parental monitoring and perceptions of children's school performance and conduct in dual- and single-earner families. Developmental Psychology, 26(4), 649-657. doi:10.1037//0012-1649.26.4.649

Parental Responsibility, Davenport Mun. Code § 9.56 .010 (2006).

Davidson, H. (1996). No consequences - Re-examining parental responsibility laws. Stanford Law and Policy Review, 7, 23-30.

Deci, E., \& Ryan, R. (1985). Intrinsic motivation and self-determination in human behavior. New York: Plenum Press.

Difonzo, J. H. (2001). Parental responsibility for juvenile crime. Oregon Law Review, 80, 1-107. Distinctive Printing and Packaging Co. v. Cox, 232 Neb. 846 (1989).

Doe v. City of Trenton, 143 N. J. Super. 128 (1976).

Duty of juvenile court to order restitution for certain unlawful acts; responsibilities of parent or guardian of child; community service in lieu of restitution. Nev. Rev. Stat. § 62E.560

Elrod, P. \& Ryder, R. S. (2005). Juvenile justice: A social, historical, and legal perspective (2nd Ed.). Sudbury, MA: Jones and Bartlett Publishers.

Erikson, E. H. (1950) Childhood and society. New York: W. W. Norton \& Company, Inc.

Erikson, E. H. (1968) Identity: youth and crisis. Oxford, UK: Norton \& Company, Inc.

Feigenson, N., \& Park, J. (2006). Emotions and attributions of legal responsibility and blame: A research review. Law and Human Behavior, 30(2), 143-161. doi:10.1007/s10979-006- 9026-z

Feld, B. (2007). A century of juvenile justice: A work in progress or a revolution that failed? Northern Kentucky Law Review, 34, 189-256.

Ferron, J., \& Rendina-Gobioff, G. (2005). Interrupted time series design. In B. S. Everitt \& D. Howell (Eds.), Encyclopedia of statistics in behavioral science. New York: Wiley. doi:10.1002/0470013192 .bsa312

Freud, S., \& Strachey, J. (1962). The ego and the id: The standard edition of the complete psychological works of Sigmund Freud. New York: W. W. Norton \& Company, Inc.

Gardner, M. R. (2009). Understanding juvenile law (3rd Ed.). Newark, NJ: LexisNexis.

Gardner, M. R., \& Dupre, A. P. (2006). Children and the law: Cases and materials. Newark, NJ: LexisNexis, Matthew Bender.

Ginsburg, G., \& Bronstein, P. (1993). Family factors related to children's intrinsic/extrinsic motivational orientation and academic performance. Child Development, 64(5), 1461-1474. doi:10.1111/ 1467-8624.ep9402220355

Ginsberg v. New York, 390 U.S. 629 (1968). 
Gladstone, I. A. (1954-1955). The legal responsibility of parents for juvenile delinquency in New York state: A developmental history. Brooklyn Law Review, 21, 172-188.

Goldberg, J., \& Zipursky, B. (2001). The restatement (third) and the place of duty in negligence law. Vanderbilt Law Review, 54, 657-750.

Gottfredson, M. R., \& Hirschi, T. (1990). A general theory of crime. Stanford, CA: Stanford University Press.

Greitemeyer, T., \&Weiner, B. (2008). Asymmetrical effects of reward and punishment on attributions of morality. Journal of Social Psychology, 148(4), 407-422. doi:10.3200/SOCP.148.4.407-422

Hall, G. S. (1904). Adolescence: Its psychology and its relation to physiology, anthropology, sociology, sex, crime, religion, and education (Vols. I \& II). Englewood Cliffs, NJ: Prentice-Hall.

Harris, L. J. (2006). An empirical study of parental responsibility laws: Sending messages, but what kind and to whom? Utah Law Review, 2006, 5-34.

Hensler v. City of Davenport, 790 N.W.2d 569 (Iowa 2010).

Hill, J. L., Waldfogel, J., Brooks-Gunn, J., \& Han, W. (2005). Maternal employment and child development: A fresh look using newer methods. Developmental Psychology, 41, 833-850. doi:10.1037/ 0012-1649.41.6.833

Hirschi, T. (1969). Causes of delinquency. Berkeley and Los Angeles: University of California Press.

Holroyd, J. (2007). A communicative conception of moral appraisal. Ethical Theory and Moral Practice, 10(3), 267-278. doi:10.1007/s10677-007-9067-5

House Bill 1299, Georgia General Assembly (1996).

Ihrie, A. D. (1996). Parental delinquency: Should parents be criminally liable for failing to supervise their children? University of Detroit Mercy Law Review, 74, 93-112.

In re Gault, 387 U.S. 1 (1967).

In re McEvoy, 267 Mich.App. 55 (2005).

In re Vera Brown, 117 Ill. App. 332 (1904).

In re Winship, 397 U.S. 358(1970).

Janoff-Bulman, R. (1979). Characterological versus behavioral self-blame: Inquiries into depression and rape. Journal of Personality and Social Psychology, 37, 1798-1809. doi:10.1037/0022-3514.37 .10 .1798

Juvenile Justice and Delinquency Prevention Act of 1972, 42 U.S.C.A. 5601 (2011).

Kassin, S. M., \& Kiechel, K. L. (1996). The social psychology of false confessions: Compliance, internalization, and confabulation. Psychological Science, 7, 125-128. doi:10.1111/j.1467-9280.1996 .tb00344.x

Kelly v. Williams, 346 S.W.2d 434 (1961).

Kent v. United States, 383 U.S. 541 (1966).

Kulik, J., \& Brown, R. (1979). Frustration, attribution of blame, and aggression. Journal of Experimental Social Psychology, 15(2), 183-194. doi:10.1016/0022-1031(79)90029-5

Lagnado, D. A., \& Channon, S. (2008). Judgments of cause and blame: The effects of intentionality and foreseeability. Cognition, 108, 754-770. doi:10.1016/j.cognition.2008.06.009

Laskin, E. R. (2000). How parental liability statutes criminalize and stigmatize minority mothers. American Criminal Law Review, 37, 1195-1217.

Leary v. U.S., 395 U.S. 6 (1969).

Lerner, M. J. (1970). The desire for justice and reactions to victims. In J. Macaulay \& L. Berkowitz (Eds.), Altruism and helping behavior (pp. 205-229). New York: Academic Press. 
Lerner, M. J., \& Matthews, G. (1967). Reactions to suffering of others under conditions of indirect responsibility. Journal of Personality and Social Psychology, 5, 319-325. doi:10.1037/ h0024304

Loeber, R., \& Schmaling, K. B. (1985). Empirical evidence for overt and covert patterns of antisocial conduct problems: A meta-analysis. Journal of Abnormal Child Psychology, 13, 337-352. doi:10.1007/ BF00910652

Maple Heights. v. Ephraim, 178 Ohio App. 3d, 439 (2008).

Mazzocco, P., Alicke, M. D., \& Davis, T. (2004). On the robustness of outcome bias: No constraint by prior culpability. Basic \& Applied Social Psychology, 26(2/3), 131-146. doi:10.1207/s15324834basp 2602\&3_3

Meier, B., \& Robinson, M. (2004).Does quick to blamemean quick to anger? The role of agreeableness in dissociating blame and anger. Personality and Social Psychology Bulletin, 30(7), 856-867. doi:10 $.1177 / 0146167204264764$

Meyer v. Nebraska, 262 U.S. 390 (1923).

Nevada Assembly Bill 39 (1997).

Ostheimer, A. L. (1939). The family: A thomistic study in social philosophy. Washington, DC: The Catholic University of America.

Owens v. Ivey, 138 Misc.2d 671 (1988).

Parkinson, B., \& Illingworth, S. (2009).Guilt in response to blame from others. Cognition and Emotion, 23, 1589-1614. doi:10.1080/02699930802591594

People v. Piccolo, 275 Ill.453 (1916).

Prince v. Massachusetts, 321 U.S. 158 (1944).

Procedure on Taking Child into Custody, Ga. Code § 15-11-47 (2000).

Reeve, C. D. C. (2004). Plato: Republic. Indianapolis, IN: Hackett Publishing Company, Inc.

Robinson, D. N. (2002). Praise and blame: Moral realism and its applications. Princeton, NJ Princeton University Press.

Rosenbaum, P. R., \& Rubin, D. B. (1983). The central role of the propensity score in observational studies for causal effects. Biometrika, 70, 41-55. doi:10.2307/2335942

Roth, M. T. (1997). Law collections from Mesopotamia and Asia Minor. Atlanta, GA: Scholars Press.

Rusinko, H., Bradley, A., \& Miller, J. (2010). Assertiveness and attributions of blame toward victims of sexual assault. Journal of Aggression, Maltreatment \& Trauma, 19(4), 357-371. doi:10.1080/1092677 1003788961

Santosky v. Kramer, 455 U.S. 745 (1982).

Scanlon, T. M. (2008). Moral dimensions: permissibility, meaning, blame. Cambridge: Belknap Press of Harvard University Press.

Scarola, T. (1997). Creating problems rather than solving them: Why criminal parental responsibility laws do not fit within our understanding of justice. Fordham Law Review, 66, 1029-1074.

Schaff, P. (1890). St. Augustine's City of God and Christian Doctrine. New York: The Christian Literature Publishing Co.

Shaffer, P. (1974). Equus and Shrivings: Two plays by Peter Shaffer. New York: Atheneum.

Shaver, K. G. (1985). The attribution of blame: Causality, responsibility, and blameworthiness. New York: Springer.

Shaver, K. G., \& Drown, D. (1986). On causality, responsibility, and self-blame: A theoretical note. Journal of Personality and Social Psychology, 50, 697-702. doi:10.1037//0022-3514.50.4. 697 
Singer, S. I. (1998). Criminal and teen courts as loosely coupled systems of juvenile justice. Wake Forest Law Review, 33, 509-532.

Sleath, E., \& Bull, R. (2010). Male rape victim and perpetrator blaming. Journal of Interpersonal Violence, 25(6), 969-988. doi:10.1177/0886260509340534

Smith, C., \& Thornberry, T. P. (1995). The relationship between childhood maltreatment and adolescent involvement in delinquency and drug use. Criminology, 33, 451-481. doi:10.1111/j.17459125.1995.tb01186.x.

Spock, B. (1957). Baby and child care. New York: Pocket Books.

Springer, E. (2008). Moral feedback and motivation: Revisiting the undermining effect. Ethical Theory and Moral Practice: An International Forum, 11(4), 407-423. doi:10.1007/s10677-008-9116-8

Struthers v. Ardale, 2000 Ohio 2610 (2000).

Stuewig, J., Tangney, J., Heigel, C., Harty, L., \& McCloskey, L. (2010). Shaming, blaming, and maiming: Functional links among the moral emotions, externalization of blame, and aggression. Journal of Research in Personality, 44(1), 91-102. doi:10.1016/j.jrp.2009.12.005

Taylor, S. E., Lichtman, R. R., \& Wood, J. V. (1984). Attributions, beliefs about control, and adjustment to breast cancer. Journal of Personality and Social Psychology, 46, 489-502. doi:10.1037//0022-3514 .46.3.489

Tennen, H., Affleck, G., \& Gershman, K. (1986) Self-blame among parents of infants with perinatal complications: The role of self-protective motives. Journal of Personality and Social Psychology, 50(4), 690-696. doi:10.1037//0022-3514.50.4.690

Testimony of Valerie Brown, Nevada Assembly Bill 39, Senate Committee, March 26, (1997). Tetlock, P., Self, W., \& Singh, R. (2010). The punitiveness paradox: When is external pressure exculpatory-And when a signal just to spread blame? Journal of Experimental Social Psychology, 46(2), 388-395. doi:10.1016/j.jesp.2009.11.013

Thistlethwaite, D. L., \& Campbell, D. T. (1960). Regression-discontinuity analysis: An alternative to the ex post facto experiment. Journal of Education Psychology, 51, 309-317. doi:10.1037/h0044319

Thurman, T. (2003). Parental responsibility laws: Are they the answer to juvenile delinquency? Journal of Family Studies, 5, 99-111.

Tilly, C. (2008). Credit and blame. Princeton, NJ: Princeton University Press.

Toliver, W. (2004). Little giant encyclopedia of inspirational quotes. Edison, NJ: Sterling Publishing Company, Inc.

Tomaszewski, A. (2005). From Columbine to Kazaa: Parental liability in a new world. University of Illinois Law Review, 2005, 573-599.

Tyler, J. E., \& Segady, T. W. (2000). Parental liability laws: Rationale, theory, and effectiveness. The Social Science Journal, 37, 79-96. doi:10.1016/S0362-3319(99)00064-6

United States v. Brown, 381 U.S. 437 (1965).

Van Vliet, K. J. (2009). The role of attributions in the process of overcoming shame: A qualitative analysis. Psychology and Psychotherapy: Theory, Research and Practice, 82, 137-152. doi:10.1348/ $147608308 \times 389391$

Weijters, G., Scheepers, P., \& Gerris, J. (2009). City and/or neighbourhood determinants? Studying contextual effects on youth delinquency. European Journal of Criminology, 6(5), 439-455. doi:10.1177/ 1477370809337883

West, E. (1996). Growing up in the twentieth-century America: A history and reference guide. Westport, CT: Greenwood Press. 
White, N. (2005). Attribution and mitigation of parent and child responsibility: A qualitative analysis. Psychiatry, Psychology, and Law, 12, 401-410. doi:10.1375/pplt.12.2.401

White, N., Augoustinos, M., \& Taplin, J. (2007). Parental responsibility for the illicit acts of their children: Effects of age, type and severity of offence. Australian Journal of Psychology, 59, 43-50.

Widom, C. S. (1989). The cycle of violence. Science, 244, 160-166. doi:10.1126/science.2704995.

Williams, G. D. (2003). Blame and responsibility. Ethical Theory and Moral Practice, 6(4), 427-445. doi:10.1023/B:ETTA.0000004627.43329.7b

Wisconsin v. Yoder, 406 U.S. 205 (1972).

Yolton, J. W., \& Yolton, J. S. (2003). Some thoughts on Education: Clarendon edition of the works of John Locke. Oxford: Oxford University Press.

Zingraff, M., Leiter, J., Myers, K., \& Johnson, M. (1993). Child maltreatment and youthful problem behavior. Criminology, 31, 173-202.

Zolman, C. L. (1998). Parental responsibility acts: Medicine for ailing families and hope for the future. Capital University Law Review, 27, 217-253.

\section{Author Biographies}

Eve M. Brank, J.D., Ph.D., University of Nebraska-Lincoln. Social Psychology, PhD: University of Nebraska-Lincoln. Dr. Brank primarily focuses on the way the law intervenes in family decisions.

Leroy B. Scott, M.A. University of Nebraska-Lincoln. Psychology, M.A.: University of NebraskaLincoln. Leroy Scott's research examines attributions of vicarious blame, vicarious responsibility, and vicarious civil liability. 